\title{
STAT3 inhibition, a novel approach to enhancing targeted therapy in human cancers (Review)
}

\author{
XIAOCHUN WANG ${ }^{1,2}$, PHILIP J. CROWE ${ }^{2}$, DAVID GOLDSTEIN ${ }^{3}$ and JIA-LIN YANG ${ }^{1,2}$ \\ ${ }^{1}$ Sarcoma Research Group, Adult Cancer Program, Lowy Cancer Research Centre, Departments of ${ }^{2}$ Surgery \\ and ${ }^{3}$ Medical Oncology, Prince of Wales Clinical School, Faculty of Medicine, \\ University of New South Wales, Randwick, NSW, Australia
}

Received December 2, 2011; Accepted February 10, 2012

DOI: $10.3892 /$ ijo.2012.1568

\begin{abstract}
Signal transducer and activator of transcription 3 (STAT3) regulates many critical functions in human normal and malignant tissues, such as differentiation, proliferation, survival, angiogenesis and immune function. Constitutive activation of STAT3 is implicated in a wide range of human cancers. As such, STAT3 has been studied as a tumour therapeutic target. This review aimed principally to summarise the updated research on STAT3 inhibition studies and their therapeutic potential in solid tumours. Recent literature associated with STAT3 inhibition was reviewed through PubMed and Medline database, followed by critical comparison and analysis. Constitutive activation of STAT3 has been identified as abnormal and oncogenic. The pathway of STAT3 activation and signal transduction identifies 3 approaches for inhibition: modulating upstream positive or negative regulators, regulating RNA (DN-STAT3, anti-sense RNA, siRNA and microRNA) or targeting STAT3 protein at different domains. The last approach using small molecule STAT3 inhibitors has been the most examined so far with both preclinical and clinical studies. Targeting STAT3 using a specific inhibitor may be a useful cancer treatment approach, with the potential for a broad clinical impact.
\end{abstract}

\section{Contents}

1. Introduction

2. Biology of STAT3

3. STAT3 inhibition and preclinical studies

4. Inhibiting STAT3 in clinical studies

5. Conclusions

Correspondence to: Dr Jia-Lin Yang, Adult Cancer Program, Level 2 Lowy Cancer Research Centre, University of New South Wales, Sydney, NSW 2052, Australia

E-mail: j.yang@unsw.edu.au

Key words: STAT3 inhibition, constitutive activation of STAT3, cancer therapy, STAT3-related microRNA, STAT3 inhibitor clinical trials

\section{Introduction}

Signal transducer and activator of transcription 3 (STAT3) is a transcription factor which in humans is encoded by the STAT3 gene. The protein is a latent cytoplasm transcription factor that relays signals of cytokines and growth factors from the cell membrane to the nucleus to regulate gene expression critical to normal cellular processes, including cell development, differentiation, proliferation, survival, angiogenesis and immune function (1-5). Constitutive STAT3 activation is associated with various human cancers and commonly suggests poor prognosis (6-9). Thus STAT3 has been studied as a tumour therapeutic target. Very recently a tumour suppressor role of STAT3 in a few tumours has also been reported $(10,11)$, but this is not the focus of the present review.

In mammals, the STAT family consists of seven protein members: STAT1, STAT2, STAT3, STAT4, STAT5a, STAT5b and STAT6, which are mapped to different human chromosomal regions (12). STAT2, STAT4 and STAT6 are only activated in normal human function, while STAT1, STAT3 and STAT5 play an important role in cancer development (STAT1 as tumour suppressor, STAT3 and STAT5 as oncogenes) $(13,14)$. STAT3 appears to be a critical regulator and is therefore the focus of this review. All of the STAT family comprise 750-850 amino acids and 6 conserved domains: the NH2-terminal, coiled-coil, DNA binding, linker, SH2, and C-terminal transactivation domains $(15,16)$. The C-terminal transactivation domain of STAT3 plays an important role in activation through a tyrosine residue at position 705 and a serine residue at position 727 (17). The SH2 region, a wellcharacterized small protein module of approximately 100 amino acids (18), is responsible for the binding of STAT3 to the tyrosine-phosphorylated receptors and also the homodimerization or heterodimerizaion of two STAT monomers that is necessary for DNA binding and gene expression (19). SH2 region, NH2-terminal and DNA-binding domain became the targets for development of STAT3 inhibitors.

This review aimed principally to summarise the therapeutic potential of STAT3 inhibitors, specifically STAT3 inhibition and preclinical studies, as well as inhibiting STAT3 in clinical trials. 
Table I. Constitutive STAT3 activation and oncogenesis.

\begin{tabular}{|c|c|c|c|c|}
\hline $\begin{array}{l}\text { Cancer } \\
\text { type }\end{array}$ & $\begin{array}{l}\text { Constitutively } \\
\text { activated STAT3 }\end{array}$ & $\begin{array}{l}\text { Mediators (or } \\
\text { regulators) }\end{array}$ & $\begin{array}{l}\text { Down-stream regulation } \\
\text { and target genes }\end{array}$ & (Refs.) \\
\hline Breast cancer & Human cell lines & $\begin{array}{l}\text { EGF/EGFR, Src, or } \\
\text { JAK }\end{array}$ & Cell cycle progression & $(61,108,109)$ \\
\hline $\begin{array}{l}\text { Endometrial and } \\
\text { cervical cancer }\end{array}$ & Human cell lines & & $\begin{array}{l}\text { Anti-apoptois by caspase- } 3 \\
\text { Genes: Bcl-X } \mathrm{X}_{\mathrm{L}} \text {, survivin and Mcl-1 }\end{array}$ & (49) \\
\hline Lung cancer & Human cell lines & $\begin{array}{l}\text { EGF/EGFR, IL-6 and } \\
\text { HGF, followed by Src, } \\
\text { or mutant EGFR or } \\
\text { CXCL12/CXCR4-JAK2 }\end{array}$ & $\begin{array}{l}\text { Anti-apoptosis } \\
\text { prolifreration }\end{array}$ & $(110-113)$ \\
\hline Multiple myeloma & Human cell lines & IL-6/JAK & $\begin{array}{l}\text { Anti-apoptosis } \\
\text { Gene: Bcl- } \mathrm{X}_{\mathrm{L}} \\
\text { cyclin D1 and p-STAT3: } \\
\text { mutually exclusive events }\end{array}$ & $(69,114)$ \\
\hline Ovarian cancer & Human cell lines & & Genes: Bcl-X $\mathrm{L}_{\mathrm{L}}$, cyclin D1 & $(47)$ \\
\hline Sarcomas & Human cell lines & & $\begin{array}{l}\text { Proliferation and anti-apoptosis } \\
\text { by caspases }\end{array}$ & $(115)$ \\
\hline $\begin{array}{l}\text { Head and neck } \\
\text { cancer }\end{array}$ & $\begin{array}{l}\text { Human HNSCC cell } \\
\text { lines, in vivo mouse } \\
\text { models, primary cultures } \\
\text { of oral keratinocytes }\end{array}$ & $\begin{array}{l}\text { IL-6/gp130, TGF- } \alpha \\
\text { or EGFR }\end{array}$ & $\begin{array}{l}\text { Proliferation, tumour } \\
\text { growth, anti-apoptosis, and } \\
\text { cell cycle progression } \\
\left(\mathrm{G}_{2}-\mathrm{M} \text { phase accumulation) }\right. \\
\text { Genes: cyclin } \mathrm{D} 1, \mathrm{Bcl}-2 \text { and } \mathrm{Bcl}-\mathrm{X}_{\mathrm{L}}\end{array}$ & $\begin{array}{l}(42,43,45 \\
46,116-118)\end{array}$ \\
\hline Prostate cancer & $\begin{array}{l}\text { Human cell lines, } \\
\text { rat cell lines, in vivo } \\
\text { mouse models }\end{array}$ & JAK 1 or JAK2 & $\begin{array}{l}\text { Proliferation, tumour growth, } \\
\text { anti-apoptosis by caspase- } 3\end{array}$ & $(25,119-122)$ \\
\hline Melanoma & $\begin{array}{l}\text { Mouse cell lines, human } \\
\text { cell lines, in vivo } \\
\text { mouse models }\end{array}$ & $\begin{array}{l}\text { Src, but not EGFR } \\
\text { or JAK }\end{array}$ & $\begin{array}{l}\text { Proliferation and anti-apoptosis } \\
\text { Genes: } \mathrm{Bcl}-\mathrm{X}_{\mathrm{L}}, \mathrm{Mcl}-1\end{array}$ & $(94,95)$ \\
\hline $\begin{array}{l}\text { Hepatocellular } \\
\text { carcinoma }\end{array}$ & $\begin{array}{l}\text { Human celll lines, } \\
\text { in vivo mouse models }\end{array}$ & $\begin{array}{l}\text { TGF- } \alpha, \text { or } \\
\text { dysfunctional } \\
\text { TGF- } \beta \text { signaling }\end{array}$ & $\begin{array}{l}\text { Proliferation } \\
\text { Genes: cyclin A, c-jun, c-fos, } \\
\text { and c-myc }\end{array}$ & $(103,123)$ \\
\hline Pancreatic cancer & $\begin{array}{l}\text { Human cell lines, } \\
\text { in vivo mouse models }\end{array}$ & & $\begin{array}{l}\text { Tumour growth, angiogenesis and } \\
\text { metastasis } \\
\text { Gene: VEGF }\end{array}$ & $(53)$ \\
\hline
\end{tabular}

\section{Biology of STAT3}

Normal function of the STAT3 pathways. The STAT3 signalling pathways regulate the gene expression of proliferation, survival, migration and invasion, as well as angiogenesis $(2,20)$ in human. Furthermore, STAT3 is essential at early stages of embryo development (21) and modulates embryonic stem cell differentiation such as TH17 helper T cells (22). In benign cells, the signalling by STAT3 is under tight regulation so that the signal is transient in accordance with physiological responses.

Activation of STAT family and associated pathways. The process of STAT activation commences with the Janus kinases (JAKs) which bind to and are phosphorylated by cytokine or growth factor receptors in response to external signals such as interleukin-6 (IL-6), interferon- $\alpha$, tumour necrosis factor (TNF), 
epidermal growth factor (EGF), platelet-derived growth factor (PDGF), transforming growth factor-alpha (TGF- $\alpha$ ) and TGF- $\beta 1$ (17,23-25). Subsequently, phosphorylated JAKs in turn cause multiple phosphorylations of tyrosine residues within the cytoplasmic domain of the cytokine receptor (26-28). Monomeric unphosphorylated STAT is recruited to these activated receptors through an interaction between the STAT SH2 domain and phosphotyrosine docking sites on the receptors. JAKs then phosporylate the critical tyrosine on C-terminal domain of STAT, which causes dissociation of STAT from the receptor, this then leads to dimerization of two STAT monomers through reciprocal interaction $(2,29,30)$. Dimeric STAT complexes translocate to the nucleus where they bind to specific DNA response elements in the promoters of target genes (31).

The non-receptor tyrosine kinases such as Src can activate the STAT signalling pathway in the absence of receptor engagement (32-34). In some cases, JAKs as intermediaries are simultaneously involved in activation of STAT by non-receptor tyrosine kinases (35).

Cross-talk with other signalling. In a hepatocellular carcinoma cell (HCC) study, JAK/STAT activated by interferon- $\alpha$ inhibited MAPK signalling by cross-talking with MEK/ERK pathway (36). Our results in sarcoma suggest this may be due to IFN $\alpha$ induced alteration of the balance between STAT1 and STAT3/ STAT5 favouring inhibition of proliferation and subsequent apoptosis (37). Cross-talking among the signalling pathways is complicated and requires further investigations. Increased understanding of cross-talking may provide the rationale for combination therapy using STAT3 inhibitor and other drugs.

Constitutive activation of STAT3 and oncogenesis. Constitutive activation of STAT3 has been reported at high frequency in large numbers of malignant cell lines, in vivo animal experiments and human tumours $(35,38,39)$. Table I includes a broad range of pre-clinical studies, which show that (activated) phosphorylatedSTAT3 (pSTAT3) is a common characteristic of many cancers. Constitutive activation of STAT3 involves multiple signalling pathways in both a cell- and tissue-specific manner, making single upstream pathway treatment difficult. So far, there has been no STAT3 gene mutation detected in any cancer. Persistent activation of STAT3 has been attributed to dysregulation of upstream tyrosine kinases and negative regulators in the STAT3 signalling pathway $(20,40)$.

Activated STAT3 regulates many genes whose expression is required in aspects of cancer initiation, development and progression, including uncontrollable proliferation, anti-apoptosis, invasion, angiogenesis and immune surveillance evasion. STAT3 signalling has been implicated in the up-regulation of cell proliferation by cylin D2 and c-Myc (20,34,41-43). In addition, pSTAT3 contributes to malignancy by preventing apoptosis, allowing accumulation of long-lived tumour cells and mediating chemoresistance via increased expression of anti-apoptotic genes such as Bcl-2 family member Bcl- $\mathrm{X}_{\mathrm{L}}$ and Mcl-2 as well as survivin (43-49). Recently, miRNA-21 has been proved to be STAT3 target gene, which functions as an inhibitor of apoptosis in multiple myeloma and Sézary cells $(50,51)$. Increased VEGF expression in cultured cell lines, animal models and patient cancer specimens, as well as tumour angiogenesis in vivo is also induced via STAT3 pathway in diverse human cancers from head, neck, breast, pancreas, cervix as well as melanoma (27,52-54). Over-expression of matrix metalloproteinase-2 (MMP-2) in melanoma and MMP-9 in breast cancer is attributed to elevated STAT3 activity $(55,56)$. STAT3, which may also be activated in tumour-infiltrating immune cells, can inhibit tumour immune function by promoting the expression of immune suppressive factors and inhibiting the product of pro-inflammatory mediators $(39,57-60)$.

Over-expression of pSTAT3 occurs in a wide range of tumours $(25,61,62)$, suggesting STAT3 may be both a therapeutic target and a clinical prognosticator. Table II outlines clinical studies of pSTAT3 expression in various human tumours. There was a significant correlation between higher pSTAT3 and worse outcomes of tumours, such as breast cancers exhibiting invasiveness, head and neck as well as gastric cancers with nodal metastasis and/or in late clinical stage, as well as prostate cancers displaying high Gleason score $(25,43,63,64)$.

The role of STAT3 as a resistance pathway to targeted therapy. As a class the targeted therapies that inhibit specific biologic pathways represent a novel therapeutic strategy either as single agents or in combination with conventional chemotherapeutics in treating a variety of malignancies. However, patient response has been less than expected and early development of resistance has been a major issue (65). The identification of novel alternative signalling pathways represents one resistance mechanism. For example one recent study demonstrated that EGFR and IGFR signal through JAK/STAT pathway, in addition to the two classical pathways of ras-raf-MEK-ERK and PI3K-Akt (66). Indeed STAT3 is a common alternative pathway for many growth promoting factors effectively bypassing a single tyrosine kinase inhibitor acting at an early point in the receptor activation pathway. For example, owing to the high level of IL-6 in NSCLC, EGFR inhibitor was ineffective due to ongoing STAT3 activation (13). STAT3 is a more downstream point of convergence in many ligand/receptor pathways (such as growth factor and cytokine receptors) and non-receptor tyrosine kinase pathways (such as Src) and consequently cross-talk among these signalling pathways may contribute to resistance to EGFR inhibitors. In addition STAT3 acts as a nuclear transcription factor (41) upregulating genes of cell survival and proliferation. Its inhibition represents a promising target for improving targeted cancer treatment in a number of preclinical studies. Furthermore, considering its late position in activation pathways, its inhibition may be less likely to be overcome through an alternative pathway.

\section{STAT3 inhibition and preclinical studies}

Since STAT3 is involved in regulating fundamental biological processes and pSTAT3 contributes to malignant transformation and progression, targeting STAT3 signalling appears to be a novel approach to preventing and treating cancers. Several strategies are being developed to target the STAT3 signalling pathway.

Modulating upstream positive or negative regulators. Inhibiting the upstream signals or enhancing negative regulators of STAT3 signalling pathway is one possible strategy.

i) Inhibition of STAT3 signalling via targeting the activation of cytokine and growth factor receptors with monoclonal antibodies or receptor antagonists: for example, the use of 
Table II. Constitutive STAT3 activation in clinical studies using human tumour specimens.

\begin{tabular}{llc}
\hline Tumour type & Expression of constitutively activated STAT3 & $\begin{array}{c}\text { Correlation with clinical } \\
\text { prognosis and parameters }\end{array}$ \\
\hline Breast cancer & 15 of $16(94 \%)$ invasive cancers, & Advanced breast cancer \\
& 1 of $8(12.5 \%)$ in situ carcinomas & \\
& 18 of $23(78 \%)$ breast tumour specimens \\
& $57 \%$ primary breast cancer specimens
\end{tabular}

Head and neck cancer

Prostate
cancer (PC)

Gastric cancer

Melanoma

Endometrial and cervical cancer

Hepatocellular carcinoma

Lung cancer

Colorectal cancer

Sarcomas 10.6-fold higher in tumours and 8.8-fold higher in normal mucosa from cancer patients compared with normal mucosa from noncancer patients

74 of $90(82 \%)$ tumour specimens

1 of $8(12.5 \%)$ premalignant lesions

19 of 51 (37\%) SCCHN tumour specimens with strong expression

7 of $10(70 \%)$ poorly differentiated tumours

44 of $45(98 \%)$ tumour specimens, 13 of $45(29 \%)$ adjacent nonjuror tissues All 24 tumours and adjacent non-tumour tissues All 15 tumour specimens

26 of $53(49 \%)$ tumour specimens

A majority of tumour specimens examined

24 of $115(21 \%)$ endometrial cancer specimens, 25 of 104 (24\%) cervical cancer specimens

All 9 HCC tissues

95 of $176(54 \%)$ NSCLC specimens

56 of $92(61 \%)$ NSCLC

46 of $92(50 \%)$ adenocarcinomas specimens

All 10 SCLC specimens

131 of 724 (18\%): hight-level pSTAT3

244 of 724 (34\%): low-level pSTAT3

21 of $113(19 \%)$ osteosarcoma, 27 of $64(42 \%)$ rhabdomyosarcoma, 22 of $151(15 \%)$ of other soft-tissue sarcoma

28 of $82(34.1 \%)$ soft tissue sarcoma
Early event in head and neck carcinogenesis

High expression in early tumour stage, subsequent degradation in late stage

Existence of nodal metastasis, late clinical stage and poor prognosis STAT1 vs STAT3 balance affects the pathogenesis of tumours

High gleason score

Severity of the malignancy

Lymph node metastasis and overall survival

Activation in early stage and throughout all stages

Limited smoking history and adenocarcinoma

Smaller tumours

Adverse clinical outcome

(higher mortality, peritumoural lymphocytic reaction)

Tumour grade, location, plane and necrosis 
Table III. Preclinical treatment of cancer by interfering STAT3 mRNA.

\begin{tabular}{|c|c|c|c|}
\hline Treatment type & Methods & Results & (Refs.) \\
\hline \multirow[t]{2}{*}{$\begin{array}{l}\text { Dominant - negative } \\
\text { mutant STAT3 }\end{array}$} & $\begin{array}{l}\text { In vitro: SCCHN, melanoma, sarcoma, } \\
\text { mammary carcinoma, prostate cancer, } \\
\text { breast cancer, endometrial and cervical } \\
\text { cancer, non-small cell lung cancer cell } \\
\text { lines }\end{array}$ & $\begin{array}{l}\text { Cell death } \uparrow \text {, apoptosis } \uparrow, \\
\text { cell proliferation } \downarrow \text {, VEGF } \downarrow \text {, } \\
\text { cell cycle arrest, cyclin D } 1 \downarrow, \\
\text { Bcl- } 2 \downarrow, \text { Bcl-X }{ }_{\mathrm{L}} \downarrow\end{array}$ & $\begin{array}{l}(27,43,49,54,61,94, \\
95,110,115-117 \\
119,122,127)\end{array}$ \\
\hline & $\begin{array}{l}\text { In vivo: mouse melanoma and human } \\
\text { prostate cancer xenografts in mice }\end{array}$ & $\begin{array}{l}\text { Tumourigenicity } \downarrow \text {, tumour growth } \downarrow \text {, } \\
\text { tumour regression } \uparrow, \text { apoptosis } \uparrow\end{array}$ & \\
\hline \multirow[t]{2}{*}{ Antisense } & $\begin{array}{l}\text { In vitro: SCCHN, melanoma, mammary } \\
\text { carcinoma, prostate cancer, non-small } \\
\text { cell lung cancer, breast cancer cell lines }\end{array}$ & $\begin{array}{l}\text { Apoptosis } \uparrow \text {, cell proliferation } \downarrow \text {, } \\
\text { VEGF } \downarrow \text {, survivin } \downarrow\end{array}$ & $\begin{array}{l}(25,45,110,116, \\
117,122,127,128)\end{array}$ \\
\hline & In vivo: $\mathrm{SCCHN}$ xenogragts in mice & Apoptosis $\uparrow$, Bcl- $\mathrm{X}_{\mathrm{L}} \downarrow$ & \\
\hline siRNA & $\begin{array}{l}\text { In vitro: breast cancer, melanoma, } \\
\text { glioma and prostate cancer cell lines } \\
\text { In vivo: glioma and prostate cancer } \\
\text { xenografts in mice }\end{array}$ & $\begin{array}{l}\text { VEGF } \downarrow \text {, cell growth } \downarrow \text {, apoptosis } \uparrow, \\
\text { Bcl-2 } \downarrow \text {, cyclin D } 1 \downarrow, \text { c-Myc } \downarrow \\
\text { Tumour growth } \downarrow \text {, apoptosis } \uparrow\end{array}$ & $(15,54,129)$ \\
\hline \multicolumn{4}{|l|}{ MicroRNA } \\
\hline Anti-let-7a & $\begin{array}{l}\text { In vitro: malignant cholangiocytes } \\
\text { In vivo: malignant cholangiocytes } \\
\text { xenograft in mice }\end{array}$ & $\begin{array}{l}\text { p-STAT3 } \downarrow \\
\text { p-STAT3 } \downarrow, \text { chemotherapy toxicity } \uparrow, \\
\text { tumour growth } \downarrow\end{array}$ & $(93)$ \\
\hline $\begin{array}{l}\operatorname{miR}-17 \text { family } \\
\text { mimic }\end{array}$ & In vitro: human breast cancer cells & STAT3 protein $\downarrow$ & $(91)$ \\
\hline
\end{tabular}

IL-6 receptor super-antagonists, such as Sant7, inhibited IL-6dependent human myeloma cell growth $\left(\mathrm{IC}_{50}=0.16 \mathrm{nM}\right)$, as well as induced cell death as a pro-apoptotic factor via STAT3 signalling $(67,68)$.

ii) Inhibition of upstream tyrosine kinases JAK or Src with small molecule inhibitors such as AG490, INCB20, PD180970 and Dasatinib: for example AG490, a JAK2-specific inhibitor, blocked constitutive activation of STAT3 causing a significant reduction of $\mathrm{Bcl}-\mathrm{X}_{\mathrm{L}}$ mRNA expression and induced cell apoptosis in certain human myeloma and prostate cancer cell lines (69). Pan-JAK inhibitor INCB20 was demonstrated to block STAT3 phosphorylation, induce apoptosis and inhibit human multiple myeloma cell growth with an $\mathrm{IC}_{50}$ of less than $1 \mu \mathrm{M}$, as well as dramatically delay tumour growth in subcutaneous xenograft model in mice (26). Dasatinib (BMS-354825), which inhibits Src tyrosine kinase activity, has shown an anti-tumour effect on head and neck squamous cell carcinoma and nonsmall cell lung cancer cells with low $\mathrm{IC}_{50}$ values in vitro (70).

iii) Enhancement of negative regulators: a number of pathways that negatively regulate STAT3 have been identified. These include suppressors of cytokine signalling (SOCS) family proteins which are transcriptionally regulated by activated STAT and form a negative feedback loop to suppress STAT signal by binding to or inhibiting JAKs or by targeting bound proteins to the proteasome degradation pathway. Other negative regulators include: protein inhibitor of activated STAT (PIAS), various tyrosine phosphatises (SHP1, SHP2, CD45), phosphatase and tensin homolog (PTEN), GRIM-19 (gene associated with retinoid IFN induced mortality-19) as well as the ubiquitin-proteasome degradation pathway involved in negative regulation of STAT signalling (71-81). Recently, neurofibromatosis 2 (NF2) tumour suppressor, schwannomin was also demonstrated to inhibit STAT3 phosphorylation (82).

However, although these are all theoretically attractive, any attempt to activate these pathways as a means of downregulating activated STAT3 is problematic owing to redundancy of upstream proteins, meaning that the STAT3 pathway might not be effectively blocked by a single compound. Furthermore, these compounds might inhibit other downstream targets, which the STAT3 signalling are cross-talking with $(39,83)$ and consequently cause undesirable side effects.

RNA interference. Another approach for STAT3 inhibition is to affect translation of STAT3 mRNA by coding RNA interference, such as domain-negative (DN) STAT3 mutants (STAT3 $\beta$, STAT3D or STAT3F), anti-sense STAT3 oligonucleotides or small interfering RNA (siRNA). Several groups reported that this strategy can inhibit cellular growth and induce apoptosis in multiple human cancer cells in vitro and in vivo, accompanied with down-regulation of STAT3 target genes. Table III lists 


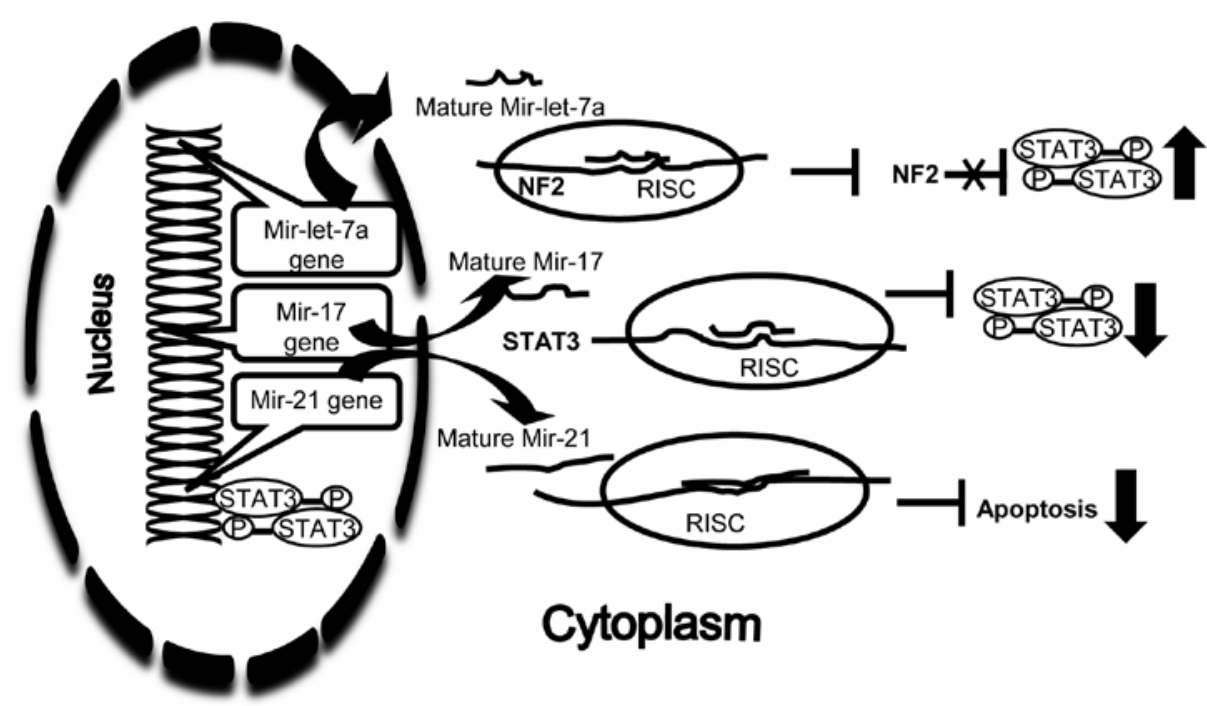

Figure 1. MicroRNAs associated with STAT3 regulation in cancer. Briefly, Mir-let-7a indirectly enhances STAT3 activation through inhibiting NF2 (negative regulator to STAT3), whilst Mir-17 directly downregulates STAT3 protein expression. In addition, mir-21 is a target gene of STAT3. Activated STAT3 binds to mir-21 gene, sequently downregulates the gene expression, and eventually leads to antiapoptosis (RISC, RNA induced silencing complex).

some RNAs used in preclinical studies, which target STAT3 mRNA.

Recently, microRNAs, small non-coding RNA molecules, which act as post-transcriptional regulators have also become the focus of research on regulation of gene activity. MicroRNA binds to the 3' untranslated regions (3' UTRs) of target mRNA in RNA induced silencing complexes (RISC), and negatively regulates gene expression through transcript destabilization and translational attenuation (84). A variety of microRNAs are linked with cancer initiation and development as tumour suppressors or oncogenes (also called oncomirs) (85-90). Several microRNAs can regulate STAT3 protein expression in embryonic development and cellular differentiation $(91,92)$. However, in tumour-related studies, only two microRNAs, mir-17 and mir-let-7a are identified to regulate STAT3 to date (Fig. 1). The Mir-17 family, as a tumour suppressor, directly regulates STAT3 mRNA expression through binding to and silencing STAT3 3' UTRs in a breast cancer cell line (MDAMB-231) (91). Mir-let-7a, as an oncogene, indirectly modulates STAT3 phosphorylation in malignant human cholangiocytes (93). Neurofibromatosis 2 (NF2), a negative regulator of STAT3 phosphorylation, is a direct target gene of mir-let-7a. As such, let-7a microRNA contributes to elevated STAT3 phosphorylation. Thus, microRNA (anti-let 7a and Mir-17 mimic) which blocks the oncogene or replace the lost suppressor function have the potential for an anti-tumour effect.

Importantly, such gene therapy displayed anti-tumour bystander effects, in which adjacent tumour cells that did not receive the gene therapy also underwent apoptosis $(94,95)$. For example, gene therapy using STAT3 $\beta$ RNA blockade caused the tumour regression seen with massive apoptosis of both transfected and bystander tumour cells.

However, more new techniques will be needed to overcome the small RNA delivery limitations and subsequent immune response in patients $(84,96)$. Some other major problems of RNA delivery include rapid excretion by kidney, degradation in extracellular fluid and permeability to the cell membrane. Nevertheless, approaches using different delivery agents (lipo- some, nanoparticle and LNA oligonucleotide) have entered preclinical and phase I clinical trials $(97,98)$.

Targeting STAT3 protein directly. The best approach may be to inhibit STAT3 protein directly. The three domains of STAT3: NH2-terminal, DNA-binding and SH2 were identified as selective targets for development of STAT3 inhibitors based on the understanding of the structure and function of STAT3 (99). The most popular target is the SH2 domain, since it is necessary for STAT3 recruiting to any activated receptor. In addition, inhibition of this target can block STAT3 dimerization and consequently inhibit nuclear translocation and STAT3-dependent gene regulation. So far, three categories of STAT3 SH2 inhibitors have been developed including peptides, peptidomimics and small molecule inhibitors. Several phosphotyrosyl peptides (PpYLKTK), tripeptides (PpYL, ApYL) and peptidomimetics (ISS610) were demonstrated to inhibit STAT3 dimerization, cell proliferation and gene regulation in vitro. PpYLKTK, PpYL and ApYL, which are STAT3 SH2 domain-binding peptides, blocked STAT3 DNA-binding activity with an $\mathrm{IC}_{50}$ of 235,182 and $217 \mu \mathrm{M}$, respectively (100). The most effective yet reported ISS610 disrupted STAT3 dimerization, inhibited cell growth and induced apoptosis, as well as reduced DNA-binding activity with an $\mathrm{IC}_{50}$ of $42 \mu \mathrm{M}$ in cells with pSTAT3 (101). However, poor cell permeability and in vivo stability is the limitation to applying peptide-based inhibitors to clinical trials (83).

Multiple novel small molecular inhibitors targeting STAT3 SH2 domain were identified and designed through structurebased high-throughout virtual screening and have been demonstrated to inhibit STAT3 dimerization and DNA-binding activity, as well as inhibit cell proliferation and tumour growth in cultured cancer cell lines and in animal models respectively. Table IV summarizes the inhibitors reported to target SH2 domain, as well as the related mechanism studies, including STA-21 and analogue, Stattic, S3I-201 (NSC 74859) and analogue, S3I-M2001, 5,15-DPP, LLL12 and STX-0119. S3I-201 selectively inhibited STAT3 DNA-binding activity, STAT3 
Table IV. Preclinical studies of small molecular inhibitors targeting STAT3 SH2 domain.

\begin{tabular}{|c|c|c|c|}
\hline Name & Studies & Discoveries & (Refs.) \\
\hline STA 21 & $\begin{array}{l}\text { Human breast cancer } \\
\text { cells, human ovarian } \\
\text { carcinoma cells } \\
\text { Osteosarcoma and } \\
\text { rhabdomyosarcoma }\end{array}$ & $\begin{array}{l}\text { STAT3 DNA-binding activity } \downarrow, \text { STAT3 } \\
\text { dimerization } \downarrow, \text { STAT3-dependent luciferase } \\
\text { activity } \downarrow \\
\text { Cells with pSTAT3: survival } \downarrow \text {, viability } \downarrow \text {, } \\
\text { growth } \downarrow \text {, apoptosis } \uparrow\end{array}$ & $(115,130)$ \\
\hline $\begin{array}{l}\text { STA-21 } \\
\text { analogue: } \\
\text { LLL-3 }\end{array}$ & Human glioblastoma & $\begin{array}{l}\text { STAT3 DNA-binding activity } \downarrow, \text { STAT3- } \\
\text { dependent transcriptional activity } \downarrow \\
\text { Cells viability } \downarrow \text {, apoptosis } \uparrow \\
\text { In vivo: survival } \downarrow \text {, intracranial } \\
\text { tumours } \downarrow, \text { contralateral invasion (-) }\end{array}$ & $(131)$ \\
\hline Stattic & $\begin{array}{l}\text { Human breast cancer } \\
\text { cell lines }\end{array}$ & $\begin{array}{l}\text { STAT3 DNA-binding activity } \downarrow, \text { STAT3 } \\
\text { dimerization } \downarrow \\
\text { Cell apoptosis } \uparrow\end{array}$ & (132) \\
\hline $\begin{array}{l}\text { S3I-201 } \\
\text { (NSC 74859) }\end{array}$ & $\begin{array}{l}\text { Human breast cancer } \\
\text { and hepatocellular } \\
\text { carcinoma }\end{array}$ & $\begin{array}{l}\text { STAT3 DNA-binding activity } \downarrow, \text { STAT3 } \\
\text { dimerization } \downarrow \text {, STAT3-dependent } \\
\text { transcriptional activity } \downarrow \\
\text { Cells growth } \downarrow \text {, apoptosis } \uparrow, \text { cyclin D1 } \downarrow, \text { Bcl-X } \mathrm{L}_{\mathrm{L}} \downarrow \text {, } \\
\text { survivin } \downarrow \\
\text { In vivo: tumour growth } \downarrow\end{array}$ & $(102,103)$ \\
\hline $\begin{array}{l}\text { S3I-201 } \\
\text { analogue: } \\
\text { S3I-201.1066 }\end{array}$ & $\begin{array}{l}\text { Human breast, pancreatic } \\
\text { and ovarian cancer cells, } \\
\text { normal human pancreatic } \\
\text { duct epithelial cells }\end{array}$ & $\begin{array}{l}\text { STAT3 DNA-binding activity } \downarrow, \text { STAT3- } \\
\text { dependent transcriptional activity } \downarrow \\
\text { Cell viability } \downarrow \text {, survival } \downarrow \text {, malignant transformation } \downarrow \text {, } \\
\text { c-Myc } \downarrow, \text { Bcl- } \mathrm{X}_{\mathrm{L}} \downarrow \text {, survivin } \downarrow, \text { MMP-9 } \downarrow, \text { VEGF } \downarrow \\
\text { In vivo: tumour growth } \downarrow\end{array}$ & $(133,134)$ \\
\hline S3I-M2001 & $\begin{array}{l}\text { Human breast and } \\
\text { pancreatic cancer cells, } \\
\text { immortalized human } \\
\text { breast epithelial cells }\end{array}$ & $\begin{array}{l}\text { STAT3 dimerization } \downarrow \text {, } \\
\text { Cells malignant transformation } \downarrow \text {, survival } \downarrow \text {, } \\
\text { migration } \downarrow \text {, invasion } \downarrow, \text { Bcl- } \mathrm{X}_{\mathrm{L}} \downarrow \\
\text { In vivo: tumour growth } \downarrow\end{array}$ & $(135)$ \\
\hline 5,15-DPP & $\begin{array}{l}\text { Human breast cell and } \\
\text { human embryonic } \\
\text { kidney cell }\end{array}$ & $\begin{array}{l}\text { STAT3 DNA-binding activity } \downarrow, \text { STAT3 translocation } \downarrow \text {, } \\
\text { STAT3 dimerization } \downarrow \text {, c-myc promoter binding } \downarrow \text {, } \\
\text { c-myc protein expression } \downarrow, \text { STAT3 and pSTAT3 unchanged }\end{array}$ & $(136)$ \\
\hline LLL12 & $\begin{array}{l}\text { Human breast and } \\
\text { pancreatic cancer cells, } \\
\text { glioblastoma cells, } \\
\text { hepatocytes, normal } \\
\text { lung fibroblasts, } \\
\text { medulloblastoma cells } \\
\text { and human hepatocytes }\end{array}$ & $\begin{array}{l}\text { STAT3 DNA-binding activity } \downarrow, \text { STAT3- } \\
\text { dependent transcriptional activity } \downarrow \text {, STAT3 } \\
\text { phosphorylation } \downarrow \text {, } \\
\text { Cell viability } \downarrow \text {, colony formation } \downarrow \text {, migration } \downarrow \text {, } \\
\text { apoptosis } \uparrow, \text { cyclin D1 } \downarrow, \text { Bcl- } 2 \downarrow, \\
\text { survivin } \downarrow \\
\text { In vivo: tumour growth } \downarrow\end{array}$ & $(137,138)$ \\
\hline STX-0119 & $\begin{array}{l}\text { Human breast cancer } \\
\text { cells, and human } \\
\text { lymphoma SCC-3 } \\
\text { xenografts in mice }\end{array}$ & $\begin{array}{l}\text { STAT3 DNA-binding activity } \downarrow, \text { STAT3 } \\
\text { dimerization } \downarrow \text {, apoptosis } \uparrow, \\
\text { c-Myc } \downarrow \text {, survivin } \downarrow \text {, cyclin D1 } \downarrow, \text { Bcl- } X_{B} \downarrow \text {, } \\
\text { In vivo: tumour growth } \downarrow\end{array}$ & $(139,140)$ \\
\hline
\end{tabular}


Table V. STAT3 inhibition in clinical trials.

\begin{tabular}{llcccc}
\hline Trial identifier & Country & Drug administration & Study duration & Phase & Patients \\
\hline NCT00511082 & Hong Kong & OPB-31121 oral & $12 / 2007-09 / 2009$ & I & $\begin{array}{l}\text { Relapsed or refractory non-Hodgkin's } \\
\text { lymphoma or multiple myeloma }\end{array}$ \\
NCT00657176 & Korea & OPB-31121 oral & $03 / 2008-06 / 2009$ & I & Advanced solid tumours \\
NCT00955812 & USA & OPB-31121 oral & $06 / 2009-02 / 2012$ & I & Advanced solid tumours \\
NCT01029509 & USA & OPB-31121 oral & $07 / 2008-07 / 2011$ & I & $\begin{array}{l}\text { Advanced leukemias or } \\
\text { myelodysplastic syndromes }\end{array}$ \\
NCT00696176 & USA & STAT3 Decoy & $08 / 2008-07 / 2011$ & 0 & $\begin{array}{c}\text { Surgically resectable head and neck } \\
\text { squamous cell carcinoma }\end{array}$
\end{tabular}

dimerization and transcriptional activity, as well as induced growth inhibition and apoptosis in cells with persistent pSTAT3 $(102,103)$. Moreover, in both human breast and hepatocellular cancer xenografts in nude mouse model, S3I-201 significantly inhibited the tumour growth with a dose of $5 \mathrm{mg} / \mathrm{kg}$. OPB-31121, another small molecule inhibitor, inhibits cell proliferation with low $\mathrm{IC}_{50}$ in a number of hematopoietic malignancy cell lines through direct blockage of STAT3 phosphorylation in preclinical studies (104). OPB-31121 has been used in clinical trials and is introduced below in the clinical study section.

Collectively, small molecule inhibitors targeting STAT3 directly are the most promising of the possible therapeutic strategies because: i) modulation of upstream regulators by single targeted therapy may not completely block the STAT3 pathway due to multiple regulators and cross-talking among pathways; ii) RNA inhibition requires yet to be identified improved techniques to deal with the delivery issues; iii) the preclinical studies demonstrate that small molecule inhibitors strongly inhibited the growth both of tumour cells in vitro and xenografts in animal models with a low $\mathrm{IC}_{50}$ encouraging clinical development and reducing the risk of development of resistance.

STAT3 inhibition combined with other targeted therapy or chemotherapy. In addition, synergy may be expected with many other inhibitors, since STAT3 is a complementary pathway for many growth factor pathways. The combination therapy of STAT3 and EGFR inhibitors synergistically and significantly suppressed cancer cell growth and down-regulated activated STAT3 expression in high-grade gliomas and pancreatic cancers $(41,105)$. Furthermore, STAT3 inhibition increased the sensitivity of cancer cells to chemotherapeutic agents such as taxol and cisplatin $(105,106)$. Therefore, STAT3 is an attractive target and some new studies on STAT3 mono-therapy and combination therapy are ongoing.

\section{Inhibiting STAT3 in clinical studies}

There are several phase 0/I clinical trials of STAT3 inhibition ongoing or not yet reported (Table V). OPB-31121, which inhibits
STAT3 phosphorylation, but did not affect JAK kinase, displayed strong anti-proliferation effect in cancer cell lines and in mouse model in vivo studies (104). Preliminary data are currently only available from one Korean study reported in the Annual Meeting of the American Society of Clinical Oncology (107) in 21 patients with advanced refractory solid tumours treated by OPB-31121. This showed that toxicities were predominantly grade 1 or 2, with the dose-limiting toxicities (DLT) of grade 3 vomiting and diarrhoea. The MTD has not been determined within the designated dose range. Eight out of 17 patients had the stable disease, with one case more than 12 months. It seems that this oral STAT3 inhibitor is safe and tolerable. More data from different clinical trials of different phases using this kind of drug are required before a clear conclusion can be made.

\section{Conclusions}

STAT3 play a pivotal role in the initiation, development and progression of cancers, including proliferation, anti-apoptosis, invasion, angiogenesis and immune surveillance evasion. Constitutively activated STAT3 is associated with a wide range of human cancers. As such, STAT3 has been identified as a novel target to treat and prevent cancers with a broad potential application. Several STAT3 inhibitors display anti-tumour effectiveness in preclinical studies. The data for clinical trials using STAT3 inhibitors are emerging. Targeting STAT3 using a specific inhibitor may be a useful cancer treatment approach, with the potential for a broad clinical impact.

\section{References}

1. Darnell JE: Transcription factors as targets for cancer therapy. Nat Rev Cancer 2: 740-749, 2002.

2. Darnell JE: STATs and gene regulation. Science 277: 1630-1635, 1997.

3. Bromberg J and Darnell JE: The role of STATs in transcriptional control and their impact on cellular function. Oncogene 19: 2468-2473, 2000.

4. Ihle JN: STATs: signal transducers and activators of transcription. Cell 84: 331-334, 1996.

5. Herrington J, Smit LS, Schwartz J and Carter-Su C: The role of STAT proteins in growth hormone signaling. Oncogene 19: 2585-2597, 2000. 
6. Alvarez JV, Greulich H, Sellers WR, Meyerson M and Frank DA Signal transducer and activator of transcription 3 is required for the oncogenic effects of non-small-cell lung cancer-associated mutations of the epidermal growth factor receptor. Cancer Res 66: 3162-3168, 2006.

7. Yin W, Cheepala S, Roberts JN, Syson-Chan K, DiGiovanni J and Clifford JL: Active Stat3 is required for survival of human squamous cell carcimoma cells in serum-free conditions. Mol Cancer 5: 15, 2006.

8. Kusaba T, Nakayama T, Yamazumi K, et al: Activation of STAT3 is a marker of poor prognosis in human colorectal cancer. Oncol Rep 15: 1445-1451, 2006.

9. Morikawa T, Baba Y, Yamauchi M, et al: STAT3 expression, molecular features, inflammation patterns, and prognosis in a database of 724 colorectal cancers. Clin Cancer Res 17: 1452-1462, 2011.

10. de la Iglesia N, Konopka G, Lim KL, et al: Deregulation of a STAT3-interleukin 8 signaling pathway promotes human glioblastoma cell proliferation and invasiveness. J Neurosci 28 : 5870-5878, 2008.

11. de la Iglesia N, Konopka G, Puram SV, et al: Identification of a PTEN-regulated STAT3 brain tumor suppressor pathway. Genes Dev 22: 449-462, 2008

12. Copeland NG, Gilbert DJ, Schindler C, et al: Distribution of the mammalian Stat gene family in mouse chromosomes. Genomics 29: 225-228, 1995 .

13. Lai SY and Johnson FM: Defining the role of the JAK-STAT pathway in head and neck and thoracic malignancies: implications for future therapeutic approaches. Drug Resist Updat 13: 67-78, 2010.

14. Quesnelle KM, Boehm AL and Grandis JR: STAT-mediated EGFR signaling in cancer. J Cell Biochem 102: 311-319, 2007.

15. Gao L, Zhang L, Hu J, et al: Down-regulation of signal transducer and activator of transcription 3 expression using vector-based small interfering RNAs suppresses growth of human prostate tumor in vivo. Clin Cancer Res 11: 6333-6341, 2005.

16. Kisseleva T, Bhattacharya S, Braunstein J and Schindler CW: Sigaling through the JAK-STAT pathway, recent advances and future challenges. Gene 285: 1-24, 2002.

17. Aggarwal BB, Kunnumakkara AB, Harikumar KB, et al: Signal tansducer and activator of transcription-3, inflammation, and cancer. Ann NY Acad Sci 1171: 59-76, 2009.

18. Pawson T, Gish GD and Nash P: SH2 domains, interaction modules and cellular wiring. Trends Cell Biol 11: 504-511, 2001

19. Zhong Z, Wen Z and Darnell JE: Stat3, a STAT family member activated by tyrosine phosphorylation in response to epidermal growth factor and interleukin-6. Science 264: 95-98, 1994.

20. Leeman R, Lui VWY and Grandis JR: STAT3 as a therapeutic target in head and neck cancer. Expert Opin Biol Ther 6: 231-241, 2006.

21. Takeda K, Noguchi K, Shi W, et al: Targeted disruption of the mouse Stat3 gene leads to early embryonic lethality. Proc Nat Acad Sci USA 94: 3801-3804, 1997.

22. Yang XO, Panopoulos AD, Nurieva R, et al: STAT3 regulates cytokine-mediated generation of inflammatory helper T cells. J Biol Chem 282: 9358-9363, 2007.

23. Miyoshi K, Takaishi M, Nakajima K, et al: Stat3 as a therapeutic target for the treatment of psoriasis: a clinical feasibility study with STA-21, a Stat3 inhibitor. J Invest Dermatol 131: 108-117, 2011.

24. Zhang HY, Zhang Q, Zhang X, et al: Cancer-related inflammation and Barrett's carcinogenesis: interleukin-6 and STAT3 mediate apoptotic resistance in transformed Barrett's cells. Am J Physiol Gastrointest Liver Physiol 300: G454-G460, 2011.

25. Mora LB, Buettner R, Seigne J, et al: Constitutive activation of Atat 3 in human prostate tumors and cell lines: direct inhibition of Stat 3 signaling induces apoptosis of prostate cancer cells. Cancer Res 62: 6659-6666, 2002.

26. Burger R, Le Gouill S, Tai Y-T, et al: Janus kinase inhibitor INCB20 has antiproliferative and apoptotic effects on human myeloma cells in vitro and in vivo. Mol Cancer Ther 8: 26-35, 2009.

27. Wei L-H, Kuo M-L, Chen C-A, et al: Interleukin-6 promotes cervical tumor growth by VEGF-dependent angiogenesis via a STAT3 pathway. Oncogene 22: 1517-1527, 2003.

28. Lopiccolo J, Blumenthal G, Bernstein WB and Dennis PA: Targeting the PI3K/Akt/mTOR pathway: effective combinations and clinical considerations. Drug Resist Updat 11: 32-50, 2008.

29. Sasse J, Hemmann U, Schwartz C, et al: Mutational analysis of acute-phase response factor/Stat 3 activation and dimerization. Mol Cell Biol 17: 4677-4686, 1997.
30. Shuai K, Horvath CM, Huang LHT, Qureshi S, Cowburn D and Darnell JE: Interferon activation of the transcription factor Stat91 involves dimerization through SH2-phosphotyrosyl peptide interactions. Cell 76: 821-828, 1994.

31. Fletcher S and Gunning PT: Mild, efficient and rapid O-debenzylation of ortho-substituted phenols with trifluoroacetic acid Tetrahedron Lett 49: 4817-4819, 2008 .

32. Yu C-L, Meyer DJ, Campbell GS, et al: Enhanced DNA-binding activity of a Stat3-related protein in cells transformed by the Src oncoprotein. Science 269: 81-83, 1995.

33. Smithgall TE, Briggs SD, Schreiner S, Lerner EC, Cheng H and Wilson MB: Control of myeloid differentiation and survial by Stats. Oncogene 19: 2612-2618, 2000.

34. Bowman T, Garcia R, Turkson J and Jove R: STATs in oncogenesis. Oncogene 19: 2474-2488, 2000.

35. Catlett-Falcone R, Dalton WS and Jove R: STAT proteins as novel targets for cancer therapy. Curr Opin Oncol 11: 490-496, 1999.

36. Inamura K, Matsuzaki Y, Uematsu N, Hondab A, Tanaka N and Uchida K: Rapid inhibition of MAPK signaling and antiproliferation effect via JAK/STAT signaling by interferon-alpha in hepatocellular carcinoma cell lines. Biochim Biophys Acta 1745: 401-410, 2005

37. Yang JL, Zahorowska B, Kasim Y, Goldstein D and Crowe P: Mechanism of the synergistic antiproliferative effect of gefitinib and interferon-alpha in sarcoma cell lines. Proc 101st Ann Meet AACR 398-399 (abs. 1655), 2010.

38. Turkson J and Jove R: STAT proteins: novel molecular targets for cancer drug discovery. Oncogene 19: 6613-6626, 2000.

39. $\mathrm{Yu} \mathrm{H}$ and Jove R: The STATs of cancer - new molecular targets come of age. Nat Rev Cancer 4: 97-105, 2004.

40. Aggarwal BB, Sethi G, Ahn KS, et al: Targeting signal-transducer-and-activator-of-transcription-3 for prevention and therapy of cancer. Ann NY Acad Sci 1091: 151-169, 2006.

41. Jaganathan S, Yue P, Paladino DC, Bogdanovic J, Huo Q and Turkson J: A functional nuclear epidermal growth factor receptor, Src and Stat 3 heteromeric complex in pancreatic cancer cells. PLoS One 6: e19605, 2011.

42. Arany I, Chen S-H, Megyesi JK, et al: Differentiation-dependent expression of signal transducers and activators of transcription (STATs) might modify responses to growth factors in the cancers of the head and neck. Cancer Lett 199: 83-89, 2003.

43. Masuda M, Suzui M, Yasumatu R, et al: Constitutive activation of signal transducers and activators of transcription 3 correlates with cyclin D1 overexpression and may provide a novel prognostic marker in head and neck squamous cell carcinoma. Cancer Res 62 $3351-3355,2002$

44. Chun K-S and Langenbach R: The prostaglandin E2 receptor, EP2, regulates survivin expression via an EGFR/STAT3 pathway in UVB-exposed mouse skin. Mol Carcinog 50: 439-448, 2011.

45. Grandis JR, Drenning SD, Zeng Q, et al: Contitutive activation of Stat3 signaling abrogates apoptosis in squamous cell carcinogenesis in vivo. Proc Natl Acad Sci USA 97: 4227-4232, 2000.

46. Kijima T, Niwa H, Steinman RA, et al: STAT3 activation abrogates growth factor dependence and contributes to head and neck squamous cell carcinoma tumor growth in vivo. Cell Growth Differ 13: 355-362, 2002.

47. Huang M, Page C, Reynolds $\mathrm{K}$ and Lin J: Constitutive activation of Stat 3 oncogene product in human ovarian carcinoma cells. Gynecol Oncol 79: 67-73, 2000.

48. Niu G, Bowman T, HUang M, et al: Roles of activated Src and Stat 3 signaling in melanoma tumor cell growth. Oncogene 21: 7001-7010, 2002.

49. Chen CL, Hsieh FC, Lieblein JC, et al: Stat 3 activation in human endometrial and cervical cancers. Br J Cancer 96: 591-599, 2007.

50. Van der Fits L, van Kester MS, Qin Y, et al: MicroRNA-21 expression in $\mathrm{CD}^{+}{ }^{+} \mathrm{T}$ cells is regulated by STAT3 and is pathologically involved in Sézary Syndrome. J Invest Dermatol 131: 762-768, 2010.

51. Loffler D, Brocke-Heidrich K, Pfeifer G, et al: Interleukin-6 dependent survival of multiple myeloma cells involves the Stat3mediated induction of microRNA-21 through a highly conserved enhancer. Blood 110: 1330-1333, 2007.

52. Ahluwalia A, Busse BA, Thiruvengadam SS and Tarnawski AS: Importins are critical for colorectal cancer (CRC) growth a nd are novel biomarkers of CRC. Underlying mechanisms include: increased nuclear transport of P-CREB and p-STAT3, VEGF gene promoter activation and aberrant VEGF expression. Gastroenterology 140: S184, 2011.

53. Wei $\mathrm{D}$, Le X, Zheng L, et al: Stat 3 activation regulates the expression of vascular endothelial growth factor and human pancreatic cancer angiogenesis and metastasis. Oncogene 22: 319-329, 2003. 
54. Xu Q, Briggs J, Park S, et al: Targeting Stat3 blocks both HIF-1 and VEGF expression induced by multiple oncogenic growth signaling pathways. Oncogene 24: 5552-5560, 2005.

55. Xie T-X, Wei D, Liu M, et al: Stat3 activation regulates the expression of matrix metalloproteinase- 2 and tumor invasion and metastasis. Oncogene 23: 3550-3560, 2004.

56. Dechow TN, Pedranzini L, Leitch A, et al: Requirement of matrix metalloproteinase-9 for the transformation of human mammary epithelial cells by Stat3-C. Proc Natl Acad Sci USA 101: 10602-10607, 2004.

57. Yu H, Kortylewski M and Pardoll D: Crosstalk between cancer and immune cells: role of STAT3 in the tumour microenvironment. Immunology 7: 41-51, 2007.

58. Kortylewski M, Kujawski M, Wang T, et al: Inhibiting Stat3 signaling in the hematopoietic system elicits multicomponent antitumor immunity. Nat Med 11: 1314-1321, 2005.

59. Kortylewski M and Yu H: Role of Stat 3 in suppressing anti-tumor immunity. Curr Opin Immunol 20: 228-233, 2008.

60. Wang T, Niu G, Kortylewski M, et al: Regulation of the innate and adaptive immune responses by Stat-3 signaling in tumor cells. Nat Med 10: 48-54, 2004

61. Garcia R, Bowman TL, Niu G, et al: Constitutive activation of STAT3 by the Src and JAK tyrosine kinases participates in growth regulation of human breast carcinoma cells. Oncogene 20: 2499-2513, 2001 .

62. Nagpal JK, Mishra R and Das BR: Activation of Stat-3 as one of the early events in tobacco chewing-mediated oral carcinogenesis. Cancer 94: 2393-2400, 2002.

63. Deng J-Y, Sun D, Liu X-Y, Pan Y and Liang H: STAT-3 correlates with lymph node metastasis and cell survival in gastric cancer. World J Gastroenterol 16: 5380-5387, 2010.

64. Watson CJ and Miller WR: Elevated levels of members of the STAT family of transcription factors in breast carcinoma nuclear extracts. Br J Cancer 71: 840-844, 1995.

65. Kosaka T, Yamaki E, Mogi A and Kuwano H: Mechanisms of resistance to EGFR TKIs and development of a new generation of drugs in non-small-cell lung cancer. J Biomed Biotechnol 2011: 1-7, 2011

66. Himpe E and Kooijman R: Insulin-like growth factor-I receptor signal transduction and the Janus kinase/signal transducer and activator of transcription (JAK-STAT) pathway. Biofactors 35: 76-81, 2009.

67. Sporeno E, Savino R, Ciapponi L, et al: Human interleukin-6 receptor super-antagonists with high potency and wide spectrum on multiple myeloma cells. Blood 87: 4510-4519, 1996.

68. Demartis A, Bernassola F, Savino R, Melino G and Ciliberto G Interleukin 6 receptor superantagonists are potent inducers of human multiple. Cancer Res 56: 4213-4218, 1996.

69. Catlett-Falcone R, Landowski TH, Oshiro MM, et al: Constitutive activation of Stat 3 signaling confers resistance to apoptosis in human U266 myeloma cells. Immunity 10: 105-115, 1999.

70. Johnson FM, Saigal B, Talpaz M and Donato NJ: Dasatinib (BMS-354825) tyrosine kinase inhibitor suppresses invasion and induces cell cycle arrest and apoptosis of head and neck squamous cell carcinoma and non-small cell lung cancer cells. Clin Cancer Res 11: 6924-6932, 2005

71. Perry E, Tsruya R, Levitsky P, et al: TMF/ARA160 is a BC-boxcontaining protein that mediates the degradation of Stat3. Oncogene 23: 8908-8919, 2004

72. Gu Q, Kong Y, Yu Z-B, Bai L and Xiao Y-B: Hypoxia-induced SOCS3 is limiting STAT3 phosphorylation and NF- $\kappa \mathrm{B}$ activation in congenital heart disease. Biochimie 93: 909-920, 2011.

73. Ulane CM, Kentsis A, Cruz CD, Parisien J-P, Schneider KL and Horvath CM: Composition and assembly of STAT-targeting ubiquitin ligase complexes: paramyxovirus $\mathrm{V}$ protein carboxyl terminus is an oligomerization domain. J Virol 79: 10180-10189, 2005.

74. Lesina M, Kurkowski Magdalena U, Ludes K, et al: Stat3/Socs3 activation by IL- 6 transsignaling promotes progression of pancreatic intraepithelial neoplasia and development of pancreatic Cancer. Cancer Cell 19: 456-469, 2011.

75. Lindemann C, Hackmann O, Delic S, Schmidt N, Reifenberger G and Riemenschneider MJ: SOCS3 promoter methylation methylation is mutually exclusive to EGFR amplification in gliomas and promotes glioma cell invasion through STAT3 and FAK activation. Acta Neuropathol 122: 241-251,2011.

76. Kluge A, Dabir S, Vlassenbroeck I, Eisenberg R and Dowlati A: Protein inhibitor of activated STAT3 expression in lung cancer. Mol Oncol 5: 256-264, 2011.
77. Migone T-S, Cacalano NA, Taylor N, Yi T, Waldmann TA and Johnston JA: Recruitment of SH2-containing protein tyrosine phosphatase SHP-1 to the interleukin 2 recepto; loss of SHP-1 expression in human T-lymphotropic virus type I-transformed T cells. Proc Natl Acad Sci USA 95: 3845-3850, 1998.

78. Schaper F, Gendo C, ECK M, et al: Activation of the protein tyrosine phosphatease SHP2 via the interleukin-6 signal transducing receptor protein gp130 requires tyrosine Jak1 and limits acute-phase protein expression. Biochem J 355: 557-565, 1998.

79. Irie-Sasaki J, Sasaki T, Matsumoto W, et al: CD45 is a JAK phosphatase and negatively regulates cytokine recptor signalling. Nature 409: 349-354, 2001.

80. Sun S and Steinberg BM: PTEN is a negative regualtor of STAT3 activation in human papillomavirus-infected cells. J Gen Virol 83 $1651-1658,2002$

81. Desrivières S, Kunz C, Barash I, Vafaizadeh V, Borghouts C and Groner B: The biological functions of the versatile transcription factors STAT3 and STAT5 and new strategies for their targeted inhibition. J Mammary Gland Biol Neoplasia 11: 75-87, 2006.

82. Scoles DR, Nguyen VD, Qin Y, et al: Neurofibromatosis 2 (NF2) tumor suppressor schwannomin and its interacting protein HRS regulate STAT singling. Hum Mol Genet 11: 3179-3189, 2002.

83. Bhasin D, Cisek K, Pandharkar T, et al: Design, synthesis, and studies of small molecule STAT3 inhibitors. Bioorg Med Chem Lett 18: 391-395, 2008

84. Esquela-Kerscher A and Slack FJ: Oncomirs - microRNAs with a role in cancer. Nat Rev Cancer 6: 259-269, 2006

85. Akao Y, Nakagawa Y and Naoe T: let-7 MicroRNA functions as a potential grwoth suppressor in human colon cancer cells. Biol Pharm Bull 29: 903-906, 2006.

86. Chan JA, Krichevsky AM and Kosik KS: MicroRNA-21 is an antiapoptotic factor in human glioblastoma cells. Cancer Res 65: 6029-6033, 2005

87. Takamizawa J, Konishi H, Yanagisawa K, et al: Reduced expression of the let-7 microRNAs in human lung cancers in association with shortened postoperative survival. Cancer Res 64: 3753-3756, 2004.

88. Yanaihara N, Caplen N, Bowman E, et al: Unique microRNA molecular profiles in lung cancer diagnosis and prognosis. Cancer Cell 9: 189-198, 2006

89. Johnson SM, Grosshans H, Shingara J, et al: RAS is regulated by the let-7 microRNA family. Cell 120: 635-647, 2005.

90. He L, Thomson JM, Hemann MT, et al: A microRNA polycistron as a potential human oncogene. Nature 435: 828-833, 2005.

91. Foshay KM and Gallicano GI: miR-17 family miRNAs are expressed during early mammalian development and regulate stem cell differentiation. Dev Biol 326: 431-443, 2009.

92. Krichevsky AM, Sonntag K-C, Isacson O and Kosik KS: Specific microRNAs modulate embryonic stem cell-derived neurogenesis. Stem Cells 24: 857-864, 2006.

93. Meng F, Henson R, Wehbe-Janek H, Smith H, Ueno Y and Patel T: The microRNA let-7a modulates interleukin-6-dependent STAT-3 survival signaling in malignant human cholangiocytes. J Biol Chem 282: 8256-8264, 2007.

94. Niu G, Heller R, Catlett-Falcone R, et al: Gene therapy with dominant-negative Stat 3 suprresses growth of the murine melanoma B16 tumor in vivo. Cancer Res 59: 5059-5063, 1999.

95. Niu G, Shain KH, Huang M, et al: Overexpression of a dominantnegative signal transducer and activator of trnascription 3 varian in tumor cells leads to production of soluble factors that induce apoptosis and cell cycle arrest. Cancer Res 61: 3276-3280, 2001.

96. Mishra PJ and Merlino G: MicroRNA reexpression as differentiation therapy in cancer. J Clin Invest 119: 2119-2123, 2009.

97. Liang Z-W, Guo B-F, Li Y, et al: Plasmid-based Stat3 siRNA delivered by hydroxyapatite nanoparticles suppresses mouse prostate tumour growth in vivo. Asian J Androl 13: 481-486, 2011.

98. Petrocca F and Lieberman J: Promise and chanllenge of RNA interference-based therapy for cancer. J Clin Oncol 29: 747-754, 2011

99. Fletcher S, Drewry JA, Shahani VM, Page BDG and Gunning PT: Molecular disruption of oncogenic signal transducer and activator of transcription 3 (STAT3) protein. Biochem Cell Biol 87: $825-833,2009$

100. Turkson J, Ryan D, Kim JS, et al: Phosphotyrosyl peptides block Stat3-mediated DNA binding activity, gene regulation, and cell transformation. J Biol Chem 276: 45443-45455, 2001.

101. Turkson J,Kim JS,Zhang S, et al: Novel peptidomimetic inhibitors of signal transducer and activator of transcription 3 dimerization and biological activity. Mol Cancer Ther 3: 261-269, 2004. 
102. Siddiquee K, Zhang S, Guida WC, et al: Selective chemical probe inhibitor of Stat3, identified through structure-based virtual screening, induces antitumor activity. Proc Natl Acad Sci USA 104: 7391-7396, 2007

103. Lin L, Amin R, Gallicano GI, et al: The STAT3 inhibitor NSC 74859 is effective in hepatocellular cancers with disrupted TGF- $\beta$ signaling. Oncogene 28: 961-972, 2009.

104. Hayakawa F, Sugimoto K, Kurahashi S, et al: A novel direct STAT3 inhibitor OPB-31121 induces tumor-specific growth inhibition in a wide 4 range of hematopoietic malignacies and effectively suppresses the chemotherapy resistant quiescent cell in vivo. 52nd ASH Ann Meet \& Expo III-56, 2010.

105. Lo H-W, Cao X, Zhu H and Ali-Osman F: Constitutively activated STAT3 frequently coexpresses with epidermal growth factor receptor in high-grade gliomas and targeting STAT3 sensitizes them to Iressa and akylators. Clin Cancer Res 14: 6042-6054, 2008.

106. Real PJ, Sierra A, De Juan A, Segovia JC, Lopez-Vega JM and Fernandez-Luna JL: Resistance to chemotherapy via Stat3dependent overexpression of $\mathrm{Bcl}-2$ in metastatic breast cancer cells. Oncogene 21: 7611-7618, 2002.

107. Oh D, Han S, Kim TM, et al: A phase I, open-label, nonrandomized trial of OPB-31121, a STAT3 inhibitor, in patients with advanced solid tumors. J Clin Oncol 28: e13056, 2010.

108. Sartor CI, Dziubinski ML, Yu C-L, Jove R and Ethier SP: Role of epidermal growth factor receptor and STAT-3 activation in autonomous proliferation of SUM-102PT human breast cancer cells. Cancer Res 57: 978-987, 1997.

109. Garcia R, Yu C-L, Hudnall A, et al: Constitutive activation of Stat3 in fibroblasts transformed by diverse oncoproteins and in breast carcinoma cells. Cell Growth Differ 8: 1267-1276, 1997.

110. Song L, Turkson J, Karras JG, Jove R and Haura EB: Activation of Stat 3 by receptor tyrosine kinases and cytokines regulates survival in human non-small cell carcinoma cells. Oncogene 22: 4150-4165, 2003

111. Haura EB, Zheng Z, Song L, Cantor A and Bepler G: Activated epidermal growth factor receptor-Stat-3 signaling promotes tumor survival in vivo in non-small cell lung cancer. Clin Cancer Res 11: 8288-8294, 2005.

112. Gao SP, Mark KG, Leslie K, et al: Mutations in the EGFR kinase domain mediate STAT3 activation via IL-6 production in human lung adenocarcinomas. J Clin Invest 117: 3846-3856, 2007.

113. Pfeiffer M, Hartmann T, Leick M, Catusse J, Schmitt-Graeff A and Burger M: Alternative implication of CXCR4 in JAK2/STAT3 activation in small cell lung cancer. Br J Cancer 100: 1949-1956, 2009.

114. Quintanilla-Martinez L, Kremer M, Specht K, et al: Analysis of signal transducer and activator of transcription 3 (Stat3) pathway in multiple myeloma, Stat 3 activation and cyclin D1 dysregulation are mutually exclusive events. Am J Pathol 162 $1449-1461,2003$

115. Chen C-L, Loy A, Cen L, et al: Signal transducer and activator of transcription 3 is involved in cell growth and survival of human rhabdomyosarcoma and osteosarcoma cells. BMC Cancer 7 : $111,2007$.

116. Grandis JR, Drenning SD, Chakraborty A, et al: Requirement of Stat 3 but not Stat 1 activation for epidermal growth factor receptormediated cell growth in vitro. J Clin Invest 102: 1385-1392, 1998.

117. Grandis JR, Zeng Q and Drenning SD: Epidermal growth factor receptor-mediated Stat 3 singaling blocks apoptosis in head and neck cancer. Laryngoscope 110: 868-874, 2000.

118. Sriuranpong V, Park JI, Amornphimoltham P, Patel V, Nelkin BD and Gutkind JS: Epidermal growth factor receptor-independent constitutive activation of STAT3 in head and neck squamous cell carcimoma is mediated by the autocrine/paracrine stimulation of the interleukin 6/gp130. Cancer Res 63: 2948-2956, 2003.

119. Ni Z, Lou W, Leman ES and Gao AC: Inhibition of constitutively activated Stat 3 signaling pathway suppresses growth of prostate cancer cells. Cancer Res 60: 1225-1228, 2000.

120. Barton BE, Murphy TF, Adem P, Watson RA, Irwin RJ and Huang HF: IL-6 signaling by STAT3 participates in the change from hyperplasia to neoplasia in NRP-152 and NRP-154 rat prostatic epithelial cells. BMC Cancer 1: 19, 2001.
121. DeMiguel F, Lee SO, Lou W, et al: Stat 3 enhances the growth of $\mathrm{LNCaP}$ human prostate cancer cells in intact and castrated male nude mice. Prostate 52: 123-129, 2002.

122. Barton BE, Karras JG, Murphy TF, Barton A and Huang HF-S: Signal transducer and activator of transcription 3 (STAT3) activation in prostate cancer: direct STAT3 inhibition induces apoptosis in prostate cancer lines. Mol Cancer Ther 3: 11-20, 2004

123. Sanchez A, Nagy P and Thorgeirsson SS: STAT-3 activity in chemically-induced hepatocellular carcinoma. Eur J Cancer 39: 2093-2098, 2003.

124. Dhir R, Ni Z, Lou W, De Miguel F, Grandis JR and Gao AC: Stat3 activation in prostatic carcinomas. Prostate 51: 241-246, 2002.

125. Sachez-Ceja SG, Reyes-Maldonado E, Vazquez-Manriquez ME, Lopez-Luna JJ, Belmont A and Gutierrez-Castellanos S: Differential expression of STAT5 and Bcl- $\mathrm{x}_{\mathrm{L}}$, and high expression of Neu and STAT3 in non-small-cell lung carcinoma. Lung Cancer 54: 163-168, 2006.

126. David D, Rajappan LM, Balachandran K, Thulaseedharan JV, Nair AS and Pillai RM: Prognostic significance of STAT3 and phosphorylated STAT3 in human soft tissue tumors - a clinicopathological analysis. J Exp Clin Cancer Res 30: 56, 2011.

127. Niu G, Wright KL, Huang M, et al: Constitutive STAT3 activity up-regulates VEGF expression and tumor angiogenesis. Oncogene 21: 2000-2008, 2002

128. Gritsko T, Williams A, Turkson J, et al: Persistent activation of Stat 3 signaling induces survivin gene expression and confers resistance to apoptosis in human breast cancer cells. Clin Cancer Res 12: 11-19, 2006

129. Gao L, Li F, Dong B, et al: Inhibition of STAT3 and ErbB2 suppresses tumor growth, enhances radiosensitivity, and induces mitochondria-dependent apoptosis in glioma cells. Intl J Radiat Oncol Biol Phys 77: 1223-1231, 2010.

130. Song H, Wang R, Wang S and Lin J: A low-molecular-weight compound discovered through virtual database screening inhibits Stat 3 function in breast cancer cells. Proc Natl Acad Sci USA 102: 4700-4705, 2005.

131. Fuh B, Sobo M, Cen L, et al: LLL-3 inhibits STAT3 activity, suppresses glioblastoma cell growth and prolongs survival in a mouse glioblastoma model. Br J Cancer 100: 106-112, 2009.

132. Schust J, Sperl B, Hollis A, Mayer TU and Berg T: Stattic: a small-molecule inhibitor of STAT3 activation and dimerization. Chem Biol 13: 1235-1242, 2006.

133. Zhang X, Yue P, Fletcher S, Zhao W, Gunning PT and Turkson J: A novel small-molecule disrupts Stat3 SH2 domain-phosphotyrosine interactions and Stat3-dependent tumor processes. Biochem Pharmacol 79: 1398-1409, 2010.

134. Fletcher S, Singh J, Zhang X, et al: Disruption of transcriptionally active Stat3 dimers with non-phosphorylated, salicylic acid-based small molecules: potent in vitro and tumor cell activities. Chem Biol Chem 10: 1959-1964, 2009.

135. Siddiquee KAZ, Gunning PT, Glenn M, et al: An oxazole-based small-molecule Stat3 inhibitor modulates Stat3 stability and processing and incuces antitumor cell effects. ACS Chem Biol 2: 787-798, 2007.

136. Uehara Y, Mochizuki M, Matsuno K, Haino T and Asai A: Novel high-throughput screening system for identifying STAT3-SH2 antagonists. Biochem Biophys Res Commun 380: 627-631, 2009.

137. Ball S, Li C, Li P-K and Lin J: The small molecule, LLL12, inhibits STAT3 phosphorylation and induces apoptosis in medulloblastoma and glioblastoma cells. PLoS One 6: e18820, 2011.

138. Lin L, Hutzen B, Li P-K, et al: A novel small molecule, LLL12, inhibits STAT3 phosphorylation and activites and exhibits potent growth-suppressive activity in human cancer cells. Neoplasia 12: $39-50,2010$.

139. Matsuno K, Masuda Y, Uehara Y, et al: Identification of a new series of STAT3 inhibitors by virtual screening. ACS Med Chem Lett 1: 371-375, 2010

140. Ashizawa T, Miyata $\mathrm{H}$, Ishii $\mathrm{H}$, et al: Antitumor activity of a novel small molecule STAT3 inhibitor against a human lymphoma cell line with high STAT3 activation. Int J Oncol 38: 1245-1252, 2011 